\title{
Experimental Tests for Gender Effects in a Principal-Agent Game
}

\section{Andrew B. Whitford*, Holona L. Ochs ${ }^{\dagger}$}

\begin{abstract}
Traditional arguments against women as leaders suggest that women would not be extended the trust necessary for leadership and/or that women undermine their own bargaining position by extending too much trust to others. We examine data from a laboratory test in which pairs of subjects are given the task of negotiating a wage-labor agreement. We first derive the optimal contract offer for principals and response by agents. We find that men and women do not reach different bargaining outcomes. We also find that women in authority are perceived as more trustworthy than men with authority, and women are no more or less trusting than men of their superiors or subordinates. The perceived trust is not rooted in differential wage terms but is based on the negotiation setting. Thus, women are likely to be extended the trust necessary to lead and are not likely to produce outcomes that are significantly different from men.
\end{abstract}

Keywords: Gender, principal-agent theory, incentives, trust, benevolence

$\mathrm{M}$ ore than 50 years have passed since the passage of the Equal Pay Act of 1963, which prohibited unequal pay for "substantially equal" work, and the Civil Rights Act of 1964, which provided protection from wage discrimination based on race, color, sex, religion, and/or national origin. The Lilly Ledbetter Fair Pay Act of 2009, authorizing lawsuits for up to 180 days after a discriminatory paycheck, and the establishment of the $\mathrm{Na}$ tional Equal Pay Task Force represent attempts to redress unequal pay. Furthermore, former President Barack Obama issued an executive order prohibiting federal contractors from discriminating against employees discussing compensation and a Presidential Memorandum requesting better data collection from federal contractors regarding employment and compensation. Despite these efforts over all this time, sizable wage disparities between women and men persist.

\footnotetext{
* School of Public \& International Affairs, University of Georgia

† Department of Political Science, Lehigh University

Address correspondence to Andrew Whitford at (aw@uga.edu)

Copyright: (C) 2019. The authors license this article under the terms of the Creative Commons Attribution 4.0 International License.
}

Public administration research consistently demonstrates that women face glass ceilings and glass walls, particularly at higher levels of leadership in federal (Crum \& Naff, 1997; Lewis \& Emmert, 1986; Naff \& Thomas, 1994) and state and local administrative positions (Bullard \& Wright, 1993; Lewis \& Nice, 1994; Reid, Kerr, \& Miller, 2000), across sectors including public education (Schuster \& Foote, 1990; Meier \& Wilkins, 2002), college administration (Pfeffer \& Davis-Blake, 1987), police administration (Garcia, 2003), and the nonprofit sector (King \& Lewis, 2017). Women also continue to face glass ceilings and glass cliffs (Mani, 1997; Sabharwal, 2013) as well as zero sum trade-offs between minorities and women in Senior Executive Service (SES) (author citation omitted). Scholars have speculated on contributing factors such as differences in negotiation strategies (Kray, Thompson, \& Galinky, 2001; Amanatullah \& Morris, 2010), confidence (Risse, Farrell, \& Fry, 2018), and trust behavior (Buchan Croson, \& Solnick, 2008). Yet, little is known as to whether or in what direction gender may or may not influence the outcomes of wage-labor agreements in public administration.

Do women obtain different outcomes in wage-labor agreements? Are there gender differences in negotiation behavior in principal-agent settings? We examine relevant evidence gathered from 
laboratory play of a principal-agent game, in which an individual (the principal, or "owner") negotiates a wage agreement that can be composed of two elements, a risky bonus and a secure flat wage, with another subject (the agent, or "contractor"). The content of the wage-labor agreement and individual assessments of the negotiation proceedings provide measures of the behavior of principals and agents and their ability and willingness to engage in contracting.

Gender differences have long been of interest to a broad array of social and biological scientists, including studies of beneficent behavior and the provision of public goods. We know that cultural norms and social identification can change the ways that individuals react to the exact same negotiation setting (e.g., Henrich et al., 2004). Cooperation levels vary across gender in public goods experiments, but it is not clear whether cooperation is higher among women or men (Brown-Kruse \& Hummels, 1993; Nowell \& Tinkler, 1994). Similar ambiguity exists in dictator experiments. Eckel and Grossman (1996) find that women are more generous than men; although Bolton \& Katok (1995) find no evidence of gender differences in generosity in dictator experiments. In ultimatum experiments, it appears that women are more likely to accept unfair offers (Eckel \& Grossman, 2001; Solnick, 2001). Croson \& Buchan (1999) and Andreoni \& Vesterlund (2001) both find asymmetric behavior by women and men in "trust-honor" and dictator games - that the likelihood of trusting, altruistic, or reciprocating behavior depends on both the position and gender of the subject, as well as the negotiation setting. Specifically, a subject's gender can provide information about the likelihood of their offering trust or being trusted, but that the information provided depends on the social setting under study, and in fact women may be less altruistic, trusting or beneficent than men (e.g., Eckel \& Grossman, 1996)..$^{1}$ One reason for the examination of gender differences is the concern that women and men might act differently in subject pools in experimental economics. ${ }^{2}$

Similarly, studies have examined persistent differences between women and men in labor market wages (Altonji \& Blank, 1999, Corcoran \& Courant, 1987; Goldin, 1990). Our tests assess whether gender is associated with different wage labor agreements in open negotiations and whether gender produces different negotiation experiences. While some evidence exists about expectations and bargaining outcomes (Solnick, 2001), evidence about wage-labor agreements is mostly based on actual labor markets (Gerhart \& Rynes, 1991) and lacks information about the choices made by principals in negotiations. In contrast, recent advances on principal-agent negotiations in laboratory settings reveal important departures from theoretical expectations about the content and impact of wagelabor agreements (e.g., Fehr et al., 1997; McLean Parks \& Conlon, 1995; Miller \& Whitford 2002; Whitford, Bottom, \& Miller, 2013; Bottom et al., 2006). Do women obtain different outcomes?

One contribution of our approach is that subjects are presented with a shared hierarchical setting where they are motivated toward self-interested behavior by economic incentives, but where subjects have competing interests regarding the way the negotiated agreement allocates risk. Specifically, principals and agents face an "insurance/incentives" tradeoff: the agent prefers risk-free compensation, but the principal - because the agent's actions cannot be monitored - prefers to make the agent's compensation contingent on the outcome of the agent's effort (Laffont \& Martimort, 2002, 41).

We test whether gender produces quantitatively different components of the wage-labor contract (measured as negotiated bonus and flat wage), and different reported attributes of the wage-labor negotiation (measured as indices perceived benevolence and trustworthiness of one's negotiating counterpart) for women and men in the roles of both principal (superior) and agent (subordinate). Our hypotheses are that women are offered less generous wage contract terms, that women offer more generous wage contract terms, that women are perceived to be and perceive others to be more benevolent, and that women are perceived to be and perceive others to be more trustworthy.

We want to be clear that even though the experimental setting may seem artificial, it provides useful information about the baseline of negotiation in all work settings. We discuss below how that baseline information helps us better understand the institutional variations that we see across the public and private sectors.

Those variations, though, have changed the nature of public work so that incentives-based compensation is much more prevalent than perhaps it was in the past. At a minimum, contracts used throughout public procurement regularly in- 
clude incentives for early completion, hitting performance metrics, inclusion of specific contract attributes, etc. We have also seen increasing use of performance-based incentives in actual hiring. Choi \& Whitford (2017) recently detailed the impact of such programs in and throughout the federal workforce (often with unintended consequences). Other local, state, and nonprofit entities in the United States have also taken on incentives as a mechanism for aligning interests. School superintendents in both the public and nonprofit sectors have complex contracts that include both fixed and variable pay. University presidents are often paid in different ways based on how they perform; likewise, college football coaches get paid flat wages and also bonuses based on winning important games. The important point here is that even the artificial game we present here speaks directly to a wide range of real-world work experiences.

This paper proceeds as follows. First, we outline the theoretical framework. We next review briefly our experimental design and method, and our specific hypotheses. After that we discuss results of the laboratory investigation, followed by a discussion of this theory, test, and implications for the study of gender in wager-labor negotiations.

\section{Theory}

Whether or not gender differences exist in negotiation settings and how such differences, if present, may affect bargaining outcomes is a timeless question. The presumption that "masculine" skills are more valuable than "feminine" skills at the bargaining table tends to be a common element of the major theoretical approaches to understanding potential gender differences in negotiations. Conclusive findings on the effect of gender in negotiation are elusive. Contradictory evidence is the norm in the literature on gender and negotiation because the context of the question is crucial to understanding gender effects (Kray \& Thompson, 2005).

The situation-based gender differences perspective posits that the situation is the primary determinant of behavior (see Cook \& Campbell, 1979). This theoretical tradition assumes that men and women are inherently alike, and when power and status, structural position, and experience are held constant, similar behaviors are elicited from both genders. Research by Riley \& McGinn (2002) supports contention that gender does not have a direct effect on bargaining outcomes but is instead contingent upon the context. In our experimental negotiation setting, we hold these properties of the negotiation context constant with the expectation that gender differences will not significantly impact bargaining behavior or outcomes.

In addition, we explore the role of trust in the principal-agent negotiating setting. We put gender stereotypes to the test. Gender stereotypes frame women as too trusting and not likely to be extended the trust necessary to lead. If assumptions about gender differences are useful mechanisms in decision-making, we might find that women are perceived as more trusting than men and that women are extended significantly less trust than men. If gender stereotypes operate, we can expect that the perception of trust will depend on the negotiation setting - on the genders of those negotiating - rather than wage terms that principal-agency theory holds paramount.

\section{Experimental Design, Method, and Hypotheses}

Our data are drawn from a larger study of a principal-agency game that had several goals beyond the study of gender differences. ${ }^{3}$ Women and men were randomly assigned to the roles of principal and agent and simultaneously randomly assigned to dyads. Each subject played a single game in which he or she negotiated with another subject in the opposite role. The game's sequence of play is as follows. The principal makes a unilateral offer of contracts to the agent. The agent chooses whether to accept the contract, and if he or she does so, the level of effort to take. Last, the payoffs stipulated in the contracts are made based on observed results.

Specifically, the principal's asset will prove to be worth either $\mathrm{S}$ or $\mathrm{F}(\mathrm{S}>\mathrm{F} \geq 0)$, depending on a random variable and agent effort. The agent's strategy set consists of three actions: HI, LO, and EXIT. For HI, the probability of $\mathrm{S}$, the successful outcome, is given by p; otherwise the outcome is F. For $\mathrm{LO}$, then the probability of $\mathrm{S}$ is given by $\mathrm{q}$ (where $\mathrm{p}>\mathrm{q}$ ). For EXIT, the asset is worth zero for sure, and both the principal and agent earn nothing for this part of the experiment. The agent experiences personal cost $C$ with $\mathrm{C}_{\mathrm{HI}}>\mathrm{C}_{\mathrm{LO}} \geq \mathrm{C}_{\mathrm{EXIT}}$ $=0$. The sequence of play is: (1) open negotiation period of fifteen minutes, (2) principal offers contract, (3) agent's participation decision, (4) agent's 
effort decision, (5) revelation of the value of the asset, and (6) contract paid off. Because of unobservable action, the principal and agent can contract only on the outcome by choosing a combination of flat wage $\mathrm{W}$ and outcome-contingent bonus $\mathrm{B}$, paid only in the event of a success $\mathrm{S}$, such that $\{\mathrm{W}, \mathrm{B}\}$ is an element of a two-dimensional space composed of real numbers ${ }^{2}$. The agent's individual rationality constraint is satisfied by bonus $\mathrm{B}^{*}$, which insures that he or she will prefer HI over LO:4

$$
p B^{*}+W-C_{H I} \geq q B^{*}+W-C_{L O}
$$

Solving for $\mathrm{B}^{*}$ :

$$
B^{*} \geq \frac{C_{H I}-C_{L O}}{p-q}
$$

The relevant attributes of the decision setting are outlined in Table 1.

Subjects were drawn from pools of university undergraduates and graduate students at one public university and one private university located in the Midwest and were recruited for each session through billboards placed around campus. Experiments were carried out in small groups with significant experimenter oversight. Once subjects were processed and informed consent was administered and agreed to, subjects then completed a pre-questionnaire that established a variety of non-invasive facts about the subject. This also provided an initial measure of risk preferences; the procedure required from five to ten minutes after subjects completed the consent form (Murnighan, Roth, \& Schoumaker, 1988; Bottom et al., 2000). Following the pre-questionnaire, the subjects read (as the experimenter read aloud) a set of instructions for the negotiation exercise. Subjects were allowed to ask questions, and then answered several questions intended to test their understanding of the exercise. Subjects who failed to answer these questions correctly received additional instruction. Different subjects participated in different sessions. For each session, subjects were assembled in a single room.

Subjects were randomly assigned to dyads, and each member of each dyad was randomly assigned to be either a contractor or an owner. The flat wage was paid whether or not the owner won the larger prize (S). The bonus was paid to the contractor only if the owner earned S. Both forms of compensation were paid out of the owner's earnings. All dyads were divided into separate rooms and negotiated without supervision. Subjects negotiated until they agreed to end the negotiation (to a wage contract), until a contractor chose to end the negotiation, or until 15 minutes elapsed. The subjects then separated; the owner had an additional two minutes to set the contract terms, which may not have been consistent with any verbal arrangement made during the negotiation period. While the owner completed the owner's post-questionnaire in a separate room, the contractor filled out a form selecting Action HI or Action LO, or EXIT (in which case there would be no compensation from this part of the game). If a contractor chose Action HI or Action LO, then the contractor also filled out a post-questionnaire. The subjects were paid a flat "show up" amount for completing the final questionnaire, which was not a factor that they could account for in the determination of their contracts. After the questionnaires were filled out and turned in, a random number process determined whether the owner won the larger or smaller prize, conditioned on the contractor's effort decision. The contractor was paid first, based on his or her effort cost, the terms of the compensation contract,

Table 1

Decision Setting

\begin{tabular}{c|c}
\hline \hline Attribute & Implementation \\
\hline Roles & Owner, Contractor \\
S (Success) & 30 \\
F (Failure) & 10 \\
p (probability of S) & 0.8 \\
q (probability of F) & 0.5 \\
C $_{\mathrm{HI}}$ & $\$ 8.50$ \\
C $_{\mathrm{LO}}$ & $\$ 5.00$ \\
Predicted Contract & $\mathrm{B}=\$ 11.67, \mathrm{~W}=\$ 0.00$ \\
\hline
\end{tabular}


and the size of the owner's prize. After the contractor was paid and dismissed, the owner was paid and dismissed. The participants never learned the contractor's effort choice and did not see one another again in the context of the experiment.

Our first hypothesis is that women who are contractors receive statistically smaller contract terms than do men.

H1: Women in the role of contractor receive smaller bonuses. H2: Women in the role of contractor receive smaller flat wages.

We also test hypotheses that women offer more beneficent wage terms than do men.

H3: Women in the role of owner offer larger bonuses. H4: Women in the role of owner offer larger flat wages.

These hypotheses follow from findings reviewed above about women's behavior in games where they contribute to a good's provision and also from non-experimental evidence about wage-labor agreements.

Post-questionnaires provide information about the subjects' evaluation of the negotiation process and serve as key variables for assessing the subjects' perceptions of the negotiation experience. First, we use a series of instruments to measure the level and quality of trust built between the pair in the negotiation (Mayer \& Davis, 1995). The MayerDavis measure addresses (1) the degree to which the contractor trusts the owner, and conversely the owner trusts the contractor (Trust), and (2) the contractor's perception of the owner's benevolence, and conversely the owner's perception of the agent's benevolence (Benevolence). Economists generally see communication during negotiation as a signaling game (Spence, 1973), and thus cheap talk (Crawford \& Sobel, 1982; McGinn et al., 2003). Yet, studies in cognitive psychology see communication as helping subjects access specialized cognitive architecture that helps with reasoning about the conditional relationships underpinning social exchange (Tooby \& Cosmides, 1992, 1996) - essentially, the ability to "detect cheating" (see also Trivers, 1971). Bottom et al. (2006) show that internal measures of the social exchange between principal and agent help explain outcomes of principal-agency negotiations. ${ }^{5}$

We test four hypotheses about benevo- lence and gender. The first two relate to the perceptions held about women in contract negotiations.

H5a: Women in the role of owner are perceived to be more benevolent than men.

H5b: Women in the role of contractor are perceived to be more benevolent than men.

We also test hypotheses about the perceptions that women hold about negotiations processes.

H6a: Women in the role of owner perceive that contractors are more benevolent than men do.

H6b: Women in the role of contractor perceive that owners are more benevolent than men do.

Our claims concern social exchange mechanisms that can underpin the negotiation process. Because of "a widespread attitude among both women and men, perhaps based on decades of women's worse labor market experience, that women will be satisfied with less" (Solnick, 2001: 189), we assess the degree to which gender changes perceptions of the counterpart's benevolence. Studies in social psychology suggest that women are more associated with helping behavior (Dovidio, 1982; Harris, 1992; Long et al., 1996).

Similarly, we test four hypotheses about trust and gender. Our first two ask whether women (as principals or agents) are considered more trustworthy.

H7a: Women in the role of owner are perceived to be more trustworthy than men.

H7b: Women in the role of contractor are perceived to be more trustworthy than men.

Our other set of hypotheses relates to the perceptions women hold about their counterparts.

H8a: Women in the role of owner perceive that contractors are more trustworthy than men $d o$.

H8b: Women in the role of contractor perceive that owners are more trustworthy than men do.

Are women more trusted? Are they more trusting? There is evidence that women are more trusted than men in non-experimental situations (Wright \& Sharp, 1979; Shaub, 1996). Experimental studies are mixed with some finding no differences (Fershtman \& Gneezy, 2001; Harbaugh et al., 2003) and others finding women to be more trustworthy 
(Buchan, Croson, \& Solnick, 2005; Chaudhuri \& Gangadharan, 2003; Croson \& Buchan, 1999). ${ }^{6}$ No studies have addressed trustworthiness and perceptions of benevolence in the context of principalagent negotiations.

It is worth noting that the experimental design attempted to capture the essential elements of principal-agency theory. For example, the owner filled out the contract unilaterally after the contractors left the room - and the owner and contractors did not meet again before they were paid separately. The negotiation stage was thus effectively structured as "cheap talk" regardless of the possible perceptions formed through the communication. The owner still moved first and had the authority to make any offer he or she wished on a take-it-orleave-it basis. Also, the experimental design incorporated differential risk aversion through manipulation by loss-framing and gain-framing (Kahneman \& Tversky 1979; Tversky \& Kahneman 1991). Specifically, loss-framed subjects take more aggressive, take-it-or-leave-it negotiating stances (Bottom \& Studt, 1993; Murnighan, Roth, \& Shoumaker, 1988). Gain-framed subjects demonstrate risk aversion by demanding larger shares of the risky prize to compensate for giving up a risk-free no-agreement alternative (Bottom, 1998). In our experiment, the owner has original ownership of the asset and is loss-framed; contractors were framed to think in terms of how much of the value of the asset they could gain through the negotiation.

\section{Results}

Table 2 provides a series of tests of our hypotheses. We have distributions of bonuses, flat wages, perceptions of benevolence, and assessments of trustworthiness for each type of interaction: for women and men in both roles.

We first test for a gender effect for the wage-labor contract terms. We do this for women and men in both roles - principal and agent - and for both contract terms - bonus and flat wage. We look for a difference in location as this is an evident summary measure of bargaining performance. Two-sample $t$-tests with the assumption of unequal variances (DeGroot \& Schervish, 2002) yield one tail $\mathrm{p}$-values for each of the four key hypotheses. ${ }^{7}$

The $t$-test assesses the difference between their means relative to the spread. ${ }^{8}$ The data suggests little evidence for locational differences in the distributions of negotiated wages for men and women. The first hypothesis that women in the role of the contractor receive smaller bonuses is not supported by the data; the resulting $t$-statistic suggests that the average bonus for men and women are not significantly different. The second is the hypothesis that women in the role of contractor receive smaller flat wages. The $t$-statistic suggests that there is no significant difference between the flat wages of women and men. Both of these differences are in the predicted direction, but neither difference is statistically-significant at conventional levels.

The data yield results that are contradictory to the third hypothesis that women in the role of owner offer larger bonuses. The $t$-statistic suggests that 9 out of 10 times there are likely to be significant differences between the average bonus offered by women and the average bonus offered by men - that more often than not, men offer significantly higher bonuses than do women. However, support for the hypothesis that women in the role of owner offer larger flat wages is not found in the data from this experiment. The $t$-statistic suggests that the average flat wage offered by women is not significantly different from that of men. Together these results offer a useful insight into the nature of munificence in principal-agency negotiations. The tests suggest that women do not compensate for smaller bonuses with larger flat (riskfree) wages, yet they do offer lower bonuses. The tests suggest that men are more likely to rely on incentives in offered contracts than are women.

We next review results from the reported perceptions of the negotiation experience. First, the results suggest no significant difference between men and women in their perceptions of the counterpart's benevolence. The $t$-statistics suggest that women are not likely to be perceived as significantly more benevolent than men in the role of owner or contractor, although the differences are in the predicted directions. Second, the $t$-statistics do not suggest significant differences for the hypotheses that women in the role of owner perceive more benevolence on the part of the contractor than men in the role of owner, and that women in the role of contractor perceive more benevolence on the part of the owner than men in the role of contractor. In this case, the tests suggest that gender does not affect perceptions of the counterpart. 
Table 2

Tests of Hypotheses

\begin{tabular}{|c|c|c|c|c|c|c|c|c|}
\hline \multirow[b]{2}{*}{ Hypothesis } & \multicolumn{3}{|c|}{ Women } & \multicolumn{3}{|c|}{ Men } & \multirow[b]{2}{*}{$\begin{array}{c}\mathrm{t} \\
\text { statistic }\end{array}$} & \multirow[b]{2}{*}{ d.f. } \\
\hline & Mean & $\begin{array}{l}\text { Std. } \\
\text { Dev. }\end{array}$ & $\mathrm{N}$ & Mean & $\begin{array}{l}\text { Std. } \\
\text { Dev. }\end{array}$ & $\mathrm{N}$ & & \\
\hline $\begin{array}{l}\text { H1: smaller bonus for women con- } \\
\text { tractors }\end{array}$ & 9.361 & 5.747 & 27 & 10.083 & 2.898 & 18 & 0.556 & 40.585 \\
\hline $\begin{array}{l}\mathrm{H} 2 \text { : smaller flat wage for women } \\
\text { contractors }\end{array}$ & 7.213 & 4.616 & 27 & 7.986 & 2.689 & 18 & 0.709 & 42.403 \\
\hline $\begin{array}{l}\text { H3: women owners offer larger } \\
\text { bonuses }\end{array}$ & 8.641 & 4.952 & 23 & 10.705 & 4.471 & 22 & $1.468^{*}$ & 42.862 \\
\hline $\begin{array}{l}\text { H4: women owners offer larger flat } \\
\text { wages }\end{array}$ & 7.391 & 3.87 & 23 & 7.659 & 4.1 & 22 & 0.225 & 42.547 \\
\hline $\begin{array}{l}\text { H5a: women owners perceived as } \\
\text { more benevolent }\end{array}$ & 0.715 & 0.152 & 23 & 0.696 & 0.13 & 22 & -0.436 & 42.502 \\
\hline $\begin{array}{l}\text { H5b: women contractors perceived } \\
\text { as more benevolent }\end{array}$ & 0.655 & 0.135 & 27 & 0.609 & 0.146 & 18 & -1.067 & 34.646 \\
\hline $\begin{array}{l}\text { H6a: women owners perceived } \\
\text { contractors as more benevolent }\end{array}$ & 0.641 & 0.162 & 23 & 0.631 & 0.115 & 22 & -0.259 & 39.746 \\
\hline $\begin{array}{l}\text { H6b: women contractors perceived } \\
\text { owners as more benevolent }\end{array}$ & 0.711 & 0.152 & 27 & 0.698 & 0.126 & 18 & -0.32 & 40.842 \\
\hline $\begin{array}{l}\text { H7a: women owners perceived as } \\
\text { more trustworthy }\end{array}$ & 0.744 & 0.093 & 23 & 0.698 & 0.072 & 22 & $-1.867 * *$ & 41.14 \\
\hline
\end{tabular}

The tests suggest that women do not experience more benevolence than men in this study, nor are they the objects of more perceived benevolence.

However, the results do suggest gender differences in levels of trust. First, the $t$-statistic for the hypothesis that women in the role of owner are perceived as more trustworthy than men in the role of owner is -1.867 , suggesting that women in the role of owner are considered more trustworthy than men in the role of owner. But the $t$-statistic suggests that women in the role of contractor are

not necessarily considered more trustworthy than men in the role of contractor. Moreover, the $t$-statistics for the hypotheses that female owners perceive the contractor to be more trustworthy than do male owners, and that female contractors perceive the owner to be more trustworthy than do male contractors suggest that women in the role of owner or contractor are not significantly more trusting than men in the roles of owner or contractor. 
We note that these results of no significant differences do not change with the inclusion of the gender of the recipient or provider of the bonus, wage, benevolence, and trust. We also assess using two-sample Wilcoxon rank-sum (Mann-Whitney) tests due to small sample sizes (Kendall \& Gibbons, 1990). We find no significant differences for the contract terms hypotheses H1 through H4. The tests suggest that women are not more beneficent as owner to female contractors, and that male owners are not more beneficent to male contractors. They also suggest that women do not receive higher bonuses or flat wages from female owners, and that men do not receive more generous contract terms from male owners. This calls into question the finding that women owners provide lower bonuses than men owners. However, the sample size and issues with the power of the tests may come into play here, and the finding may not be specific to a contractor's gender.

Similarly, perceptions of a contractor's or owner's benevolence do not appear to depend on the concordance of the two parties' genders, indicating that the findings from the $t$-tests can be disaggregated and still support inference of no differences in helping behavior. Two findings do attain limited significance though for trusting behavior. First, female contractors report more trust for female owners than for male owners $(Z=1.610$, twotailed test). Second, male contractors report more trust for female owners than for male owners $(\mathrm{Z}=$ 1.653, two-tailed test). (Both results border on significance at the $\mathrm{p}=0.10$ level.) No other significant differences are apparent for trust of contractors by owners. Together, these results suggest support for differential trust felt by contractors of owners based on the owner's gender. This is similar to results reported above in trust-honor games.

\section{Discussion}

The principal-agency game examined here indicates little difference between men and women in the outcomes of negotiations, and only a few differences in the perceived trustworthiness of women compared to men. Our results suggest that women do not obtain negotiation outcomes significantly different from men. In the context of principalagent relationships, men and women behave in accordance with their role in the negotiation. Although men offer somewhat larger bonuses in the role of principal than women in the role of principal, the tests suggest that gender has little effect on the choices made in the determination of contract terms or the outcome of negotiations. This provides a measure of evidence for the position that the persistent differences between women and men in wages in the labor market are not due to differences in the contracts men and women negotiate. However, these findings must be interpreted as suggestive and necessitate replication because the sample size limits the power of our tests.

Our results relate to the findings of Bolton \& Katok (1995) that men and women may bargain differently but not differ in generosity. Substantive differences in the bargaining behavior of men and women can be expected to be evidenced in differences in bargaining outcomes. However, we find little evidence that men and women reach different bargaining outcomes, and women are not necessarily more generous than men (see Eckel \& Grossman, 1996), as is indicated by the somewhat larger bonuses offered by men in the role of owner. Additionally, Eckel \& Grossman (2000) find that the choices women make are less individually-oriented, but these findings are conditioned on the level of risk. Consequently, the hierarchical setting of the principal-agent game presented here controls for potential patterned differences in the relative risk orientation of women and men, and our data shows that men and women are equally motivated toward self-interested behavior by economic incentives.

These findings also lend additional support for the notion that women are more trusted than men (e.g.; Wright \& Sharp, 1979; Shaub, 1996), which has particular importance in managerial and other hierarchical settings. We find that women with authority are perceived as more trustworthy than men with authority. We also find that women are no more or less trusting than men of their superiors or subordinates. This seems to suggest that women are more likely to be extended trust, and the likelihood that women extend trust to men is not significantly different from that of men-that perceived trust is not rooted in differential wage terms but is based on the negotiation setting.

It is important to position these findings vis-à-vis the longstanding public administration concern for the opportunities for women in public sector work settings. The data and tests we report here are suggestive, but they are suggestive in ways that make the studies reported above even more 
important for understanding women in work settings. One way to interpret those existing studies is that they pay attention to the broader institutions that shape the opportunities for and constraints on women in those settings. We applaud that attention and believe that our research report shows how institution-free environments (like experiments) which do not exist in the real world - provide a baseline to measure how institutions shape the behavior of real public workers in real agencies.

We want to be clear that experiments can be useful for understanding institutional differences. Those assessments are beyond the scope of study here but an important next step in the evolution of workplace negotiations. Obviously, some institutional variations affect all workers the same and indeed, they reduce the likelihood that genderbased perceptions can affect outcomes. But in many cases, those variations fundamentally shape outcomes across units and individuals (perhaps nowhere so clear as in the case of local-level bargaining in small units like charter schools). Experiments can help us predict the performance of those variations in the real world. But those predictions depend on knowing upfront the baseline performance expected from people like the women and men who make up the public sector workforce.

\section{Notes}

1. To this list we can add the large number of studies of gender differences in the experimental psychology literature. Kray \& Thompson (2005) point out the difficulty of directly comparing multidisciplinary studies because of fundamental differences in the methodological characteristics, and because of the nature of principal-agency theory, we concentrate on economic approaches. See Brown-Kruse \& Hummels (1993) for a review of relevant literature. Such research has yielded a wealth of contradictory findings, and recent large scale meta-analytic reviews of the literature on gender differences in negotiation (Walters, Stuhlmacher, \& Meyer, 1998; Stuhlmacher \& Walters, 1999; Babcock \& Laschever, 2003) suggest that differences between men and women in negotiation behaviors are small.
2. See Henrich et al., (2010) for a compelling analysis of the limitations of experimental research that relies on Western, Industrialized, Educated, Rich, and (economically) Developed (WIERD) subject pools from which claims about human nature or behavior are often derived.

3. There were other treatments in the larger study, but they involved modifications of the game that renders the resulting data inappropriate for our present study.

4. To satisfy the agent's participation constraint, the bonus should prevent the agent from exiting: $\mathrm{B}^{* *} \geq \mathrm{C}_{\mathrm{HI}} / \mathrm{p}$.

5. Our Trust and Benevolence scales are constructed to closely connect to the bargaining problem confronting the players. When assessing the principal, the agent was essentially given the original version of the scale. When assessing the agent, the principal was given a version that reversed the direction of the relationship. For example, on the Benevolence scale Mayer and Davis ask for agreement with the statement, "Top management will go out of its way to help me." In the principal's version the wording was changed to "The agent will go out of his/her way to help me." Both Benevolence and Trust were measured by five separate items and five-point Likert-type response scales. As Mayer \& Davis (1995) also found, the internal consistency for this scale was quite high.

6. We note that in contrast to some studies, our study controls for agent ability (which can be related to trusting behavior) by design: the marginal efficacy of the agent is part of the experimental design.

7. The sample sizes here are sufficient for assessment by $t$-test rather than the use of rank-order tests (Kendall \& Gibbons, 1990). We discuss results based on rank-order tests below.

8. Post hoc power analysis using G*Power 3.1.9.2 (Faul, Erdfelder, Lang, \& Buchner, 2007; Faul et al., 2009) indicates that a sample size of 50 for each group is necessary to achieve sufficient power. This suggests that our experimental data is somewhat under-powered and that our findings need to be put in perspective as such. 


\section{References}

Altonji, J., \& Blank, R. (1999). Race and gender in the labor market. In O. Ashenfelter \& D. Card (Eds.), Handbook of labor economics. Volume 3C. Amsterdam: Elsevier Science, North Holland.

Amanatullah, E. T., \& Morris, M. W. (2010). Negotiating gender roles: Gender differences in assertive negotiating are mediated by women's fear of backlash and attenuated when negotiating on behalf of others. Journal of Personality and Social Psychology, 98(2), 256-267. doi:10.1037/a0017094

Andreoni, J., \& Vesterlund, L. (2001). Which is the fair sex? Gender differences in altruism. Quarterly Journal of Economics, 116(1), 293-312. doi:10.1162/003355301556419

Babcock, L., \& Laschever, S. (2003). Women don't ask: Negotiation and the gender divide. . Princeton, NJ: Princeton University Press.

Bolton, G. E., \& Katok, E. (1995). An experimental test for gender differences in beneficent behavior. Economics Letters, 48(3), 287-292. doi:10.1016/01651765(94)00621-8

Borrelli, M., \& Martin, J. M. (1997). The other elites: Women, politics, and power in the executive branch. Boulder: Lynne Rienner.

Bottom, W. P. (1998). Negotiator risk: Sources of uncertainty and the impact of reference points on negotiated agreements. Organizational Behavior and Human Decision Processes, 76(2), 89-112.

Bottom, W. P., Holloway, J., McClurg, S., \& Miller, G. J. (2000). Negotiating a coalition: Risk, quota shaving, and learning to bargain. Journal of Conflict Resolution, 44(2), 147-169. doi:10.2307/174661

Bottom, W. P., Holloway, J., Miller, G. J., Mislin, A., \& Whitford, A. (2006). Building a pathway to cooperation: Negotiation and social exchange between principal and agent. Administrative Science Quarterly, 51(1), 29-58. doi:10.2189/asqu.51.1.29

Bottom, W. P., \& Studt, A. (1993). Framing effects and the distributive aspect of integrative bargaining. $\mathrm{Or}$ ganizational Behavior and Human Decision Processes, 56(3), 459-474. doi:10.1006/obhd.1993.1064

Brown-Kruse, J., \& Hummels, D. (1993). Gender effects in laboratory public goods contribution: Do individuals put their money where their mouth is? Journal of Economic Behavior \& Organization, 22(3), 255-267. doi:10.1016/0167-2681(93)90001-6

Buchan, N. R., Croson, R. T. A., \& Solnick, S. (2008). Trust and gender: An examination of behavior and beliefs in the investment game. Journal of Economic Behavior \& Organization, 68(3-4), 466-476. doi:10.1016/j.jebo.2007.10.006

Bullard, A. M., \& Wright, D. S. (1993). Circumventing the glass ceiling: Women executives in American state governments. Public Administration Review, 53(3), 189202. doi:10.2307/3110123
Chaudhuri, A., \& Gangadharan, L. (2003). Gender differences in trust and reciprocity. Working paper. Washington State University.

Choi, S., \& Whitford, A. B. (2017). Employee satisfaction in agencies with merit-based pay: Differential effects for three measures. International Public Management Journal, 20(3), 442-466. doi:10.1080/10967494.2016.1269860

Cook, T., \& Campbell, D. (1979). Quasi-experimentation: Design and analysis issues for field settings. Chicago: Rand McNally.

Corcoran, M. E., \& Courant, P. N. (1987). Sex-role socialization and occupational segregation: An exploratory investigation. Journal of Post Keynesian Economics, 9(3), 330-346. doi:10.1080/01603477.1987.11489627

Crawford, V. P., \& Sobel, J. (1982). Strategic information transmission. Econometrica, 50(6), 1431-1451. doi:10.2307/1913390

Croson, R., \& Buchan, N. (1999). Gender and culture: International experimental evidence from trust games. American Economic Review, 89(2), 386-391. doi:10.2307/117141

Crum, J., \& Naff, K. C. (1997). Looking like america: The continuing importance of affirmative action in federal employment. Public Productivity \& Management Review, 20(3), 272-287. doi:10.2307/3380977

DeGroot, M. H., \& Schervish, M. J. (2002). Probability and statistics. Boston: Addison-Wesley.

Dovidio, J. F. (1982). Sex, costs, and helping behavior. Journal of Psychology, 112(2), 231-236. doi:10.1080/00223980.1982.9915379

Eckel, C., \& Grossman, P. (2000). Differences in the economic decisions of men and women: Experimental evidence. In C. Plott \& V. L. Smith (Eds.), Handbook of Results in Experimental Economics. New York: North Holland.

Eckel, C., \& Grossman, P. (2001). Chivalry and solidarity in ultimatum games. Economic Inquiry, 39(2), 171-188. doi:10.1111/j.1465-7295.2001.tb00059.x

Eckel, C. C., \& Grossman, P. J. (1996). The relative price of fairness: gender differences in a punishment game. Journal of Economic Behavior \& Organization, 30(2), 143158. doi:10.1016/s0167-2681(96)00854-2

Faul, F., Erdfelder, E., Buchner, A., \& Lang, A.-G. (2009). Statistical power analyses using $G^{*}$ Power 3.1: Tests for correlation and regression analyses. Behavior research methods, 41(4), 1149-1160. doi:10.3758/brm.41.4.1149

Faul, F., Erdfelder, E., Lang, A.-G., \& Buchner, A. (2007). G*Power 3: A flexible statistical power analysis program for the social, behavioral, and biomedical sciences. Behavior research methods, 39(2), 175-191.

Fehr, E., Gächter, S., \& Kirchsteiger, G. (1997). Reciprocity as a contract enforcement device: Experimental evidence. Econometrica, 65(4), 833-860. 
doi:10.2307/2171941

Fershtman, C., \& Gneezy, U. (2001). Discrimination in a segmented society: An experimental approach. Quarterly Journal of Economics, 116(1), 351-377. doi:10.1162/003355301556338

Garcia, V. (2003). "Difference" in the police department: Women, policing, and "doing gender". Journal of Contemporary Criminal Justice, 19(3), 330-344. doi:10.1177/1043986203254530

Gerhart, B., \& Rynes, S. L. (1991). Determinants and consequences of salary negotiations by male and female MBA graduates. Journal of Applied Psychology, 76(2), 256-262. doi:10.1037/0021-9010.76.2.256

Goldin, C. (1990). Understanding the gender gap. New York: Oxford University Press.

Harbaugh, W. T., Krause, K., Liday Jr., S. G., \& Vesterlund, L. (2003). Trust in children. In E. Ostrom \& J. Walker (Eds.), Trust, reciprocity and gains from association: Interdisciplinary lessons from experimental research. New York: Russell Sage Foundation.

Harris, M. B. (1992). When courtesy fails: Gender roles and polite behaviors. Journal of Applied Social Psychology, 22(18), 1399-1416. doi:10.1111/j.1559-1816.1992.tb00956.x

Henrich, J., Boyd, R., Bowles, S., Camerer, C., Fehr, E., \& Gintis, H. (2004). Foundations of human sociality: Economic experiments and ethnographic evidence from fifteen smallscale societies. New York: Oxford University Press.

Henrich, J., Heine, S. J., \& Norenzayan, A. (2010). The weirdest people in the world? Behavioral and brain sciences, 33(2-3), 61-83. doi:10.1017/s0140525x0999152x

Kahneman, D., \& Tversky, A. (1972). Subjective probability: A judgment of representativeness. Cognitive Psychology, 3(3), 430-454. doi:10.1016/0010-0285(72)90016-3

Kendall, M., \& Gibbons, J. D. (1990). Rank correlation methods. Oxford: Edward Arnold.

King, C., \& Lewis, G. B. (2017). Nonprofit pay in a competitive market: Wage penalty or premium? Nonprofit and Voluntary Sector Quarterly, 46(5), 1073-1091. doi:10.1177/0899764017718633

Kray, L., \& Thompson, L. (2005). Gender stereotypes and negotiation performance: A review of theory and research. In B. Straw \& R. Kramer (Eds.), Research in Organizational Behavior Series, 26. Amsterdam: Elsevier.

Kray, L. J., Thompson, L., \& Galinsky, A. (2001). Battle of the sexes: Gender stereotype confirmation and reactance in negotiations. Journal of Personality and Social Psychology, 80(6), 942-958.

Laffont, J.-J., \& Martimort, D. (2002). The theory of incentives. Princeton: Princeton University Press.

Lewis, G. B., \& Emmert, M. A. (1986). The sexual division of labor in federal employment. Social Science Quarterly, 67(1), 143-156.

Lewis, G. B., \& Nice, D. (1994). Race, sex, and occupational segregation in state and local governments.
American Review of Public Administration, 24(4), 393-410. doi:10.1177/027507409402400404

Long, D. A., Mueller, J. C., Wyers, R., Khong, V., \& Jones, B. (1996). Effects of gender and dress on helping behavior. Psychological Reports, 78(3), 987-994. doi:10.2466/pr0.1996.78.3.987

Mani, B. G. (1997). Gender and the federal senior executive service: Where is the glass ceiling? Public Personnel Management, 26(4), 545-558. doi:10.1177/009102609702600411

Mayer, R. C., \& Davis, J. H. (1999). The effect of the performance appraisal system on trust for management: A field quasi-experiment. Journal of Applied Psychology, 84(1), 123-136. doi:10.1037/0021-9010.84.1.123

McGinn, K. L., Thompson, L., \& Bazerman, M. H. (2003). Dyadic processes of disclosure and reciprocity in bargaining with communication. Journal of Behavioral Decision Making, 16(1), 17-34. doi:10.1002/bdm.430

Miller, G. J., \& Whitford, A. B. (2002). Trust and incentives in principal-agent negotiations: The insurance/incentive trade-off. Journal of Theoretical Politics, 14(2), 231-267. doi:10.1177/095169280201400204

Murnighan, J. K., Roth, A. E., \& Schoumaker, F. (1988). Risk aversion in bargaining: An experimental study. Journal of Risk and Uncertainty, 1(1), 101-124. doi:10.1007/bf00055566

Naff, K. C., \& Thomas, S. (1994). The glass ceiling revisited: Determinants of federal job advancement. Review of Policy Research, 13(3-4), 249-272. doi:10.1111/j.1541-1338.1994.tb00606.x

Nowell, C., \& Tinkler, S. (1994). The influence of gender on the provision of a public good. Journal of Economic Behavior \& Organization, 25(1), 25-36. doi:10.1016/0167-2681(94)90084-1

Parks, J. M., \& Conlon, E. J. (1995). Compensation contracts: Do agency theory assumptions predict negotiated agreements? Academy of Management Journal, 38(3), 821-838. doi: $10.2307 / 256747$

Pfeffer, J., \& Davis-Blake, A. (1987). The effect of the proportion of women on salaries: The case of college administrators. Administrative Science Quarterly, 32(1), 124. doi: $10.2307 / 2392740$

Reid, M., Kerr, B., \& Miller, W. H. (2000). A study of the advancement of women in municipal government bureaucracies: Persistence of glass ceilings? Women \& Politics, 21(1), 35-53. doi:10.1300/J014v21n01_02

Riley, H., \& McGinn, K. (2002). When does gender matter in negotiation? Kennedy School of Government Faculty Working Paper Series, RWP02-036.

Sabharwal, M. (2013). From glass ceiling to glass cliff: Women in senior executive service. Journal of Public Administration Research and Theory, 25(2), 399-426. doi:10.1093/jopart/mut030

Schuster, D. J., \& Foote, T. H. (1990). Differences abound between male and female superintendents. The School Administrator, 47, 14-19. 
Shaub, M. K. (1996). Trust and suspicion: The effects of situational and dispositional factors on auditors' trust of clients. Behavioral Research in Accounting, 8, 154-174.

Solnick, S. (2001). Gender differences in the ultimatum game. Economic Inquiry, 39(2), 189-200. doi:10.1111/j.1465-7295.2001.tb00060.x

Spence, M. (1973). Job market signaling. Quarterly Journal of Economics, 87(3), 355-374. doi:10.2307/1882010

Stuhlmacher, A. F., \& Walters, A. E. (1999). Gender differences in negotiation outcomes: A meta-analysis. Personnel Psychology, 52, 653-677.

Tooby, J., \& Cosmides, L. (1992). The psychological foundations of culture. In J. H. Barkow, L. Cosmides, \& J. Tooby (Eds.), The adapted mind: Evolutionary psychology and the generation of culture. New York: Oxford University Press.

Tooby, J., \& Cosmides, L. (1996). Friendship and the banker's paradox: Other pathways to the evolution of adaptations for altruism. In W. G. Runciman, J. M. Smith, \& R. I. M. Dunbar (Eds.), Proceedings of The British Academy, Vol. 88. Evolution of social behaviour patterns in primates and man (pp. 119-143). New York, NY, US:
Oxford University Press.

Trivers, R. L. (2015). The evolution of reciprocal altruism. Quarterly Review of Biology, 46(1), 35-57. doi:10.1086/406755

Tversky, A., \& Kahneman, D. (1991). Loss aversion in riskless choice: A reference-dependent model. Quarterly Journal of Economics, 106(4), 1039-1061. doi: $10.2307 / 2937956$

Walters, A. E., Stuhlmacher, A. F., \& Meyer, L. L. (1998). Gender and negotiator competitiveness: A meta-analysis. Organizational Behavior and Human Decision Processes, 76(1), 1-29. doi:10.1006/obhd.1998.2797

Whitford, A. B., Bottom, W. P., \& Miller, G. J. (2013). The (negligible) benefit of moving first: Efficiency and equity in principal-agent negotiations. Group Decision and Negotiation, 22(3), 499-518. doi:10.1007/s10726-011-9280-4

Wright, T. L., \& Sharp, E. G. (1979). Content and grammatical sex bias on the intertemporal trust scale and differential trust towards woman and men. Journal of Consulting and Clinical Psychology, 47, 72-85. 